\title{
Diversity of Insect Pest and Predator Species in Monsoon and Summer Rice Fields of Taungoo Environs, Myanmar
}

\author{
San San 0o' ${ }^{*}$, Khin Myat Hmwe1, Nyo Nyo Aung1, Aye Aye Su', Khin Khin Soe', \\ Tin Lay Mon', Khin Mar Lwin², May Myat Thu3 ${ }^{3}$, Thin Thin Soe ${ }^{2}$, Myat Lwin Htwe ${ }^{2}$ \\ ${ }^{1}$ Zoology Department, University of Yangon, Yangon, Myanmar \\ ${ }^{2}$ Zoology Department, Kyaing Tong University, Kyaing Tong, Myanmar \\ ${ }^{3}$ Zoology Department, Dagon University, Yangon, Myanmar \\ Email: *sansanooyu@gmail.com
}

How to cite this paper: Oo, S.S., Hmwe, K.M., Aung, N.N., Su, A.A., Soe, K.K., Mon, T.L., Lwin, K.M., Thu, M.M., Soe, T.T. and Htwe, M.L. (2020) Diversity of Insect Pest and Predator Species in Monsoon and Summer Rice Fields of Taungoo Environs, Myanmar. Advances in Entomology, 8, 117-129.

https://doi.org/10.4236/ae.2020.83009

Received: May 13, 2020

Accepted: May 31, 2020

Published: June 3, 2020

Copyright $\odot 2020$ by author(s) and Scientific Research Publishing Inc. This work is licensed under the Creative Commons Attribution International License (CC BY 4.0).

http://creativecommons.org/licenses/by/4.0/

\section{(c) (i) Open Access}

\begin{abstract}
Paddy fields are natural and artificial wetland ecosystems that supply rice for the people and provide the wildlife especially insect diversity of different functional aspects. A total of 71 insect species belonging to 40 families under eight orders were observed during the study period. Among the 71 insect species, 18 species of beetles, nine species of bugs, eight species of dragonfly, five species of butterflies, four species of leafhoppers, plant hoppers and moths, three borer and spiders, two crickets, one species of skippers, grass hopper, hispa, ant, weevil, hairy caterpillar, leaf roller, katydid, thrips, maggot and water boatmen were recorded in the study sites. Total of 41 species of pests, 18 species of predators and 12 species of beneficial species (they function as pollinating the flowering plants in the paddy field wetland ecosystem) were recorded in the study sites. In the monsoon season, the 41 species of pest species, 18 species of predator species and 12 species of beneficial species were recorded from monsoon rice field. According to Shannon Evenness value $\left(H^{\prime} / S=-0.012564\right)$, the data showed that the insect species recorded from the one habitat was not the similar to another. In summer paddy fields, 36 species of pest species, 16 species of predator species and 9 species of beneficial species were recorded. Total arthropod insect species were recorded 61 species from the dry rice fields. According to Shannon Evenness value $\left(H^{\prime} / S=\right.$ -0.000120 ), the data showed that the insect species recorded from the one habitat was not the similar to another. Population growth and duration of life cycle of insects is mainly dominated by the temperature, the duration of life cycle is shorter in the high temperature than in the low temperature.
\end{abstract}




\section{Keywords}

Indent, Insect Species Diversity, Pest and Predators, Seasonal Variation, Paddy Filed, Taungoo

\section{Introduction}

The insects play an important role in the paddy field ecosystem functioning as pests and their counter action of predator insects. The insects are the highest diversity among about $90 \%$ or more of global living species exist on earth planet. Most insects are destructive, vectors and predators. Among them, the pest species destroyed the plant species especially agricultural crops.

Insects are responsible for two major forms of damage to crops. These include aphids, whiteflies and scaled insects. Rice (Oryza sativa) is the staple food of over half of the world's population. Annual world rice production is approximately 460 million tons grown on more than 145 million hectare (ha). Over $90 \%$ of the world's rice is grown in Asia. The government has accorded the highest priority on the rice sector because of its crucial role in food security, economic and political importance to the country [1].

Myanmar is an agricultural country, having over 8 million hectares of paddy land, all are growing monsoon rice and in some of these fields where there is irrigating by the dams, the summer rice are growing. Monsoon rice occupies the largest portion of the rice area $80 \%$ and summer rice is $20 \%$. There are about 70 rice varieties have been collected in Myanmar (IRRI), all have particular characters possessing good and bad. Twenty-eight varieties of these are widely grown by farmers. Rice varieties vary in characteristics such as grain length, thickness, color and aroma. The incidents of the pests are dependent on the varieties of rice species [2].

Insects are major constraint to rice production. Most of the rice plant parts are vulnerable by the insects feeding throughout the growing season from the time of sowing to the harvesting. Both the mature and immature stages of insects injure rice plants by chewing leaf and root tissues, boring and tunneling into stems, or sucking fluid sap from stems and grains. The injury from feeding of insects leads to damage showing symptoms of skeletonized and defoliated leaves, dead hearts, whiteheads, stunted and wilted plants and unfilled or picky grains. Ultimately insect damage affects the plant physiology leading to reduction in measurable yield, utility or economic return [3]. As the insect pests cause damage to rice plants and are one of the reasons of total annual yield loss of rice, it is important to study the rice insect pests, especially their seasonal abundance and incidence, to evaluate the control measures. Notable works on the rice field insect pests are those of Alam [4] [5]. The entomologists of BRRI initiated systematic surveys of rice field insect pests throughout Bangladesh dividing Bangladesh into several agro-ecological zones and collected rice insect pests from dif- 
ferent crops, seasons and growth stages of the rice plants [6]-[11].

The arthropod community in rice fields includes rice pests, their natural enemies (predators and parasitoids) and other non-rice pest insects that inhabit or visit the vegetation. Over 800 species of arthropod community in rice ecosystem have been reported worldwide. The composition of the arthropod communities in the rice ecosystem is mainly influenced by the rice plants [10].

Irrigated rice fields are agronomically managed wetland ecosystems with a high degree of environmental heterogeneity operating on a short temporal scale, harbour a rich and varied fauna [11]. The fauna is dominated by micro (bacteria), meso (insects) and macro invertebrates (especially arthropods) inhabiting the soil, water and vegetation sub-habitats of the rice fields. The terrestrial arthropod community in rice fields consists mainly of insects and spiders (terrestrial invertebrates). The different communities of terrestrial arthropods in the rice field include rice pests, their natural enemies (predators and parasitoids) and other non-rice pest insects that inhabit or visit the vegetation which are collectedly known as beneficial insects although spiders are under the class Insecta [6].

The cultivation of rice in Myanmar varies according to seasonal changes and the availability of water supply. It is grown extensively throughout the country in three seasons. There are mainly two rice growing seasons, dry season rice and monsoon rice. The dry and humid climate of Myanmar is conductive to the proliferation of insect pests. The two rice crops grown under diverse ecological conditions are attacked throughout the growing periods by a number of insect pests of the 70 species of rice insect species recorded in Myanmar, 40 - 43 species have been found to be more damaging. The magnitude of damage varies in seasons, years and locations.

The climate condition of Taungoo environs was moist humid in monsoon season (a range of temperature of between $32.5^{\circ} \mathrm{C}$ and $39^{\circ} \mathrm{C}$; that of humidity of $84.5-96 \mathrm{~mm}$ and rainfall with $103 \mathrm{~cm}$ ) and hot dry in summer season (range of temperature between $22.5^{\circ} \mathrm{C}$ and $33^{\circ} \mathrm{C}$; that of humidity of $41.5-63.0 \mathrm{~mm}$ ) according to Department of Meteorology and Hydrology, Taungoo Township. The rice fields in Myanmar have diverse ecological conditions and presence of rice field insect pests is expected to be variable. But no attempt has been made to study the rice field insect pests in the Taungoo of Bago Region. The present study was aimed to prepare a list of rice field insect pests, their abundance and incidence on different stages of rice plants and in different growing seasons. This study was to access the abundance category, dominant index, Shannon index diversity of the paddy field ecosystem, and to compare the two ecosystems of monsoon and summer rice fields from Taungoo area of Myanmar.

\section{Materials and Methods}

\subsection{Study Area and Study Period}

Taungoo Township is located in upper part of Bago Region, eastern part of Middle Yoma Mountain range and close to lower boundary of Mandalay Region. It 
is one high species diversity region. Soil types and weather condition is favorable condition for the growing paddy and other varieties of crops including peas and beans. Four paddy fields with an area of one hectare each from villages of Taungoo Township were selected as follows: Study site 1: around Nat Sin Gon village (N 18 59'31.40" and E 96 17'40.15"); Study site 1I: Along the road sides of Saba Oo village (N 18 $56^{\prime} 23.04^{\prime \prime}$ and E $\left.96^{\circ} 17^{\prime} 53.80^{\prime \prime}\right)$; Study site III: Nyaung kaing village (N 18 $58^{\prime} 53.49^{\prime \prime}$ and E $\left.96^{\circ} 15^{\prime} 54.77^{\prime \prime}\right)$; Study site IV: Htain Kone Pin village (N $18^{\circ} 57^{\prime} 17.87^{\prime \prime}$ and E $\left.96^{\circ} 18^{\prime} 29.21^{\prime \prime}\right)$. The study period lasted from July, 2017 to May, 2018 (Figure 1).

\subsection{Sample Collection}

Five transect lines were designated evenly apart each other. Five sampling plots were located on each transect line. The insect specimens from all survey sites from both seasons of monsoon and summer were weekly collected during the time from 7:00 am to 5:00 pm. During the day time, insect net were also used by sweeping the net. The nocturnal insects were also collected using light traps, light traps were set out each corners of the paddy field and one was at the centre of the field. The collected specimens were socked out into different insect groups as butterflies, beetles, etc. and they were identified down into species levels depending into taxonomic and morphological characters. Those species were categorized as pests, predators and beneficial groups depending on the infestation and predation during the observation time and the confirmed with the references.

\subsection{Data Analysis}

Two parameters to access the insect diversity and Relative abundance of the recorded species were calculated. The Shannon index and Evenness formula were used for the assessment of insect species diversity as follows (Stiling, 1999) [12].

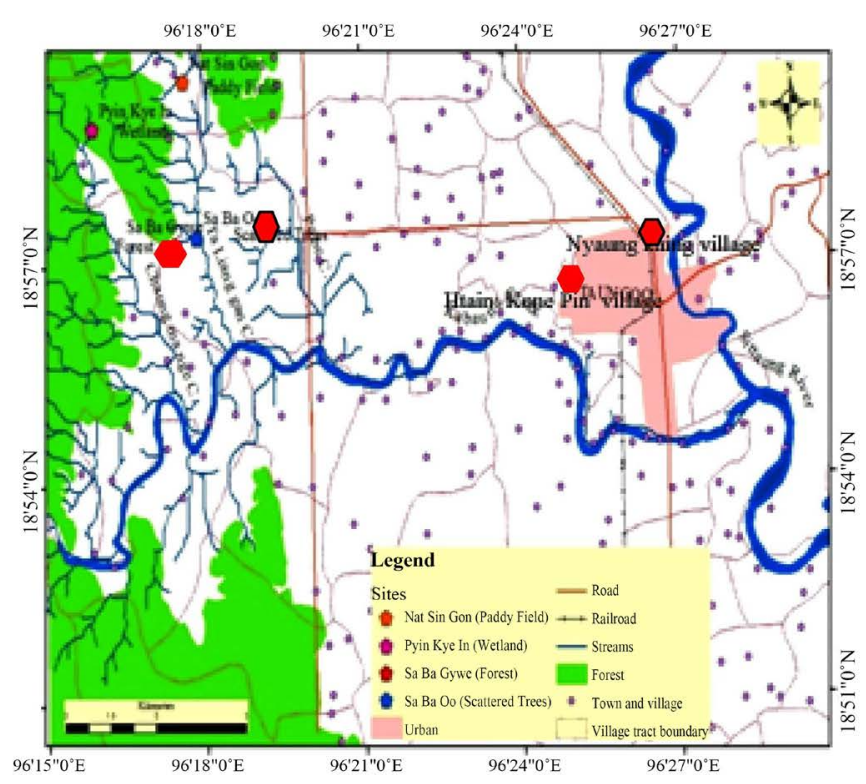

$=$ Study sites

Figure 1. Map of Taungoo environs showing the four study site. 


\section{Equation 1}

$$
\begin{gathered}
\text { Shannon Index }=H^{\prime}=\sum P i \ln P i \\
\text { Shannon Index }=H^{\prime} / S \\
P i=\frac{\text { No. of insect species }}{\text { Total No. of all bird species }} \times 100
\end{gathered}
$$

where, $\operatorname{Ln}=$ Log Normal,

$S=$ Total numbers of species.

Relative abundance of monthly occurrence was also calculated based on each species. The calculation was followed after Kumar and Sivaperuman (2005) [13].

Equation 2

$$
\text { Relative abundance }=\frac{\text { Total No. of partiular species }}{\text { Total No. of all species }} \times 100
$$

The range of index value for the Abundance categories were determined as

Rare Species $=(0.1-2.0)$

Common $=(6.1-8.0)$

Uncommon $=(2.1-4.0)$

Abundant $=(8.1-$ above $)$

Frequent $=(4.1-6.0)$

\subsection{Identification}

Identification was followed after Bingham (1905) [14], Bingham (1907) [15], Talbot (1939) [16], Kinyon (2004) [17].

\section{Results and Discussion}

The paddy field ecosystem was composted of a total of 71 insect species belonging to 40 families under nine orders with the three spider species. Among the 71 insect species, 18 species of beetles, nine species of bugs, eight species of dragonfly, five species of butterflies, four species of leafhoppers, plant hoppers and moths, three borer and spiders, two crickets, one species of skippers, grass hopper, hispa, ant, weevil, hairy caterpillar, leaf roller, katydid, thrips, maggot and water boatmen were recorded in the study sites (Table 1). Hence, those paddy fields were functioning ecosystem and healthy community and participate in every tropic level of these ecosystems. The insects are small animal functioning in various tropic levels. As a biodiversity conservation point of view, these paddy fields were sustainable ecosystem (Table 1 and Table 2).

The paddy field ecosystem was highly diverse insect species and spiders inhibiting 71 species representing 40 families in the monsoon rice plantation and 32 families in summer rice growing season (Table 2 and Figure 2). The species numbers under nine orders, Order Coleoptera, Diptera, Hemiptera, Orthroptera, Hymenoptera, Lepidoptera, Odonata, Thysamoptera and Aracnidae decreased in summer while it was more or less similar in both paddy growing seasons. The insect species numbers and its relative abundance was higher because they didn't applied the pesticides for this research and the surrounding paddy fields usually control the pest insects as chemical control. This area is also not far to the deciduous forest of Middle Yoma mountain range. 
Table 1. Collected insect species from the paddy fields of Taungoo township.

\begin{tabular}{|c|c|c|c|c|}
\hline ORDER/FAMILY & No. & Scientific Name & Common Name & Habit \\
\hline \multicolumn{5}{|l|}{ I. COLEOPTERA } \\
\hline Anobiidae & 1. & Xestobium rufovillosum & Deathwatch beetle & Pest \\
\hline Bostrichidae & 2. & Heterobostrychus aequalis & Oriental wood borer & Beneficial \\
\hline Carabidae & 3. & Harpalus rufipes & Strawberry seed beetle & Pest \\
\hline Coccinellidae & 4. & Micraspis discolor & Lady bug beetle & Predator \\
\hline \multirow[t]{7}{*}{ Chrysomelidae } & 5. & Aulocophora foveicollis & Red pumpkin beetle & Pest \\
\hline & 6. & Aulocophora nigripennis & Leaf beetle & Pest \\
\hline & 7. & Cassoda flaveola & Pale tortoise beetle & Pest \\
\hline & 8. & Gastrophysa atrocyanea & Leaf bee & Pest \\
\hline & 9. & Hoplasaenide acapitata & Leaf beetle & Pest \\
\hline & 10. & Monolepta australis & Red shouldered leaf beetle & Pest \\
\hline & 11. & Dicladispa armigera & Rice hispa & Pest \\
\hline Curculionidae & 12. & Sitophilus oryzae & Weevil & Pest \\
\hline Dermestidae & 13. & Anthrenus sp. & Carpet beetle & Beneficial \\
\hline Hydrophilidae & 14. & Hydrophilus triangularis & Water scavenger beetle & Beneficial \\
\hline \multirow[t]{2}{*}{ Scaravaeidae } & 15. & Heteronychus lioderes & Scarab beetle & Pest \\
\hline & 16. & Phyllophaga sp. & May beetle & Pest \\
\hline \multirow[t]{2}{*}{ Staphylinidae } & 17. & Paederus dermatitis & Rove beetle & Predator \\
\hline & 18. & Xylodromus sp. & Rove beetle & Predator \\
\hline \multicolumn{5}{|l|}{ II. DIPTERA } \\
\hline Ephydridae & 19. & Hydrellia philippina & Whorl maggot & Pest \\
\hline \multicolumn{5}{|l|}{ III. HEMIPTER } \\
\hline \multirow[t]{2}{*}{ Alydidae } & 20. & Stenocoris sp. & Rice bug & Pest \\
\hline & 21. & Leptocorisa oratorius & Rice water bug & Pest \\
\hline \multirow[t]{5}{*}{ Cicadellidae } & 22. & Cofana spectra & White leafhopper & Pest \\
\hline & 23. & Empoasca fabae & Leafhopper & Pest \\
\hline & 24. & Nephotettix virescens & Leafhopper & Pest \\
\hline & 25. & Recilia dorsalis & $\begin{array}{l}\text { Zigzag leafhopper white } \\
\text { backed plant }\end{array}$ & Pest \\
\hline & 26. & Nephotettix nifropictus & Hopper & Pest \\
\hline Corixidae & 27. & Corixa punctata & Water boatmen & Beneficial \\
\hline \multirow[t]{3}{*}{ Delphacidae } & 28. & Nilaparvata lugens & Brown plant hopper & Pest \\
\hline & 29. & Delphacodes sp. & Brown plant hopper & Pest \\
\hline & 30 & Sogatella furcifera & Plant hopper & Pest \\
\hline Dictyopharidae & 31. & Rhynochomitra microrhina & Green plant hopper & Pest \\
\hline Miridae & 32. & Phytocoirs sp. & Bug & Beneficial \\
\hline Lygaeidae & 33. & Scolopostethus pictus & Bug & Beneficial \\
\hline Cydnidae & 34. & Pangaeus bilineatus & Burrowing bug & Pest \\
\hline Pentatomoidae & 35. & Scotinopharaco arctata & Black bug & Pest \\
\hline
\end{tabular}




\section{Continued}

\begin{tabular}{|c|c|c|c|c|}
\hline Pyrrhocoroidae & 36. & Dysdercus cingulatus & Red cotton bug Assassin & Beneficial \\
\hline Reduviidae & 37. & Sirthenea dimidiate & Dansel bug & Pest \\
\hline Pentatomidae & 38. & Nezara viridula & Green Stink Bug & Pest \\
\hline \multicolumn{5}{|c|}{ IV. HYMENOPTERA } \\
\hline Formicidae & 39. & Solenopsis geminate & Alate queen ant & Predator \\
\hline \multicolumn{5}{|l|}{ V. ORTHOPTERA } \\
\hline Acrididae & 40. & Oxya chinensis & Rice grasshopper & Pest \\
\hline \multirow[t]{2}{*}{ Grylidae } & 41. & Gryllus texensis & Field cricket & Pest \\
\hline & 42. & Anaxipha sp. & Field cricket & Predator \\
\hline Tettigoniidae & 43. & Conocephalus fasciatus & Katydid & Predator \\
\hline \multicolumn{5}{|l|}{ V. LEPIDOPTERA } \\
\hline \multirow[t]{5}{*}{ Crambidae } & 44. & Scirphphaga praelata & Moth & Pest \\
\hline & 45. & Scirphphaga intertulus & Stem borer & Pest \\
\hline & 46. & Marasmia exigua & Rice leaf roller dark-headed & Pest \\
\hline & 47. & Chilo polychrysus & Striped borer & Pest \\
\hline & 48. & Chilo suppressalis & Striped rice stem borer & Pest \\
\hline \multirow[t]{3}{*}{ Erebidae } & 49. & Cretonotos gangis & Hairy caterpillar & Pest \\
\hline & 50. & Laelia coenosa & Moth & Pest \\
\hline & 51. & Orygia sp. (caterpillar) & Tusock moth & Pest \\
\hline Hersperiidiae & 52. & Pelopidas mathias & Rice skipper & Pest \\
\hline Sphingidae & 53. & Theretra shendurneensis & Moth & Pest \\
\hline \multirow[t]{4}{*}{ Nymphalidae } & 54. & Danaus chrysippus & Butterfly & Beneficial \\
\hline & 55. & Junonia almanac & Butterfly & Beneficial \\
\hline & 56. & Junonia atlites & Butterfly & Beneficial \\
\hline & 57. & Melanitisleda ismene & Rice butterfly & Beneficial \\
\hline Pieridae & 58. & Eurema hecabe & Butterfly & Beneficial \\
\hline Pyralidae & 59. & Cnaphalocrocis medinalis & Rice leaf folder & Pest \\
\hline \multicolumn{5}{|l|}{ VII. ODONATA } \\
\hline \multirow[t]{8}{*}{ Libellulidae } & 60. & Acisoma panorpoides & Dragonfly & Predator \\
\hline & 61. & Brachythemis contaminate & Dragonfly & Predator \\
\hline & 62. & Crocothemis erythraea & Dragonfly & Predator \\
\hline & 63. & Diplacodes nebulosa & Dragonfly & Predator \\
\hline & 64. & Diplacodes trivalis & Dragonfly & Predator \\
\hline & 65. & Neurothemistullia tullia & Dragonfly & Predator \\
\hline & 66. & Orthetrum sabina & Dragonfly & Predator \\
\hline & 67. & Trithemis kirbyi kirbyi & Dragonfly & Predator \\
\hline
\end{tabular}

VIII. THYSANOPTERA

Thripidae

XI. ARANEAE
68. Stenchaetothrips biformis

Rice thrips

Pest

Orb-weaver spider Predator Spider Predator Agelenidae 70. Tegenaria $s p$.

71. Nesticus cellulanus
Spider 
Table 2. Species composition in different families of insects and spiders from the paddy fields.

\begin{tabular}{cccccc}
\hline \multirow{2}{*}{ Sr. No. } & Order & \multicolumn{2}{c}{ Monsoon season } & \multicolumn{2}{c}{ Summer season } \\
\cline { 3 - 6 } & & No. of Family & No. of Species & No. of Family & No. of Species \\
\hline 2. & Coleoptera & 10 & 18 & 9 & 15 \\
3. & Diptera & 1 & 1 & 1 & 1 \\
4. & Hymenoptera & 1 & 19 & 8 & 15 \\
5. & Orthoptera & 3 & 1 & 0 & 2 \\
6. & Lepidoptera & 7 & 4 & 2 & 16 \\
7. & Odonata & 1 & 16 & 7 & 8 \\
8. & Thysamoptera & 1 & 8 & 1 & 1 \\
9. & Aracnidae & 3 & 1 & 1 & 3 \\
Total & & 40 & 3 & 32 & 61 \\
\hline
\end{tabular}

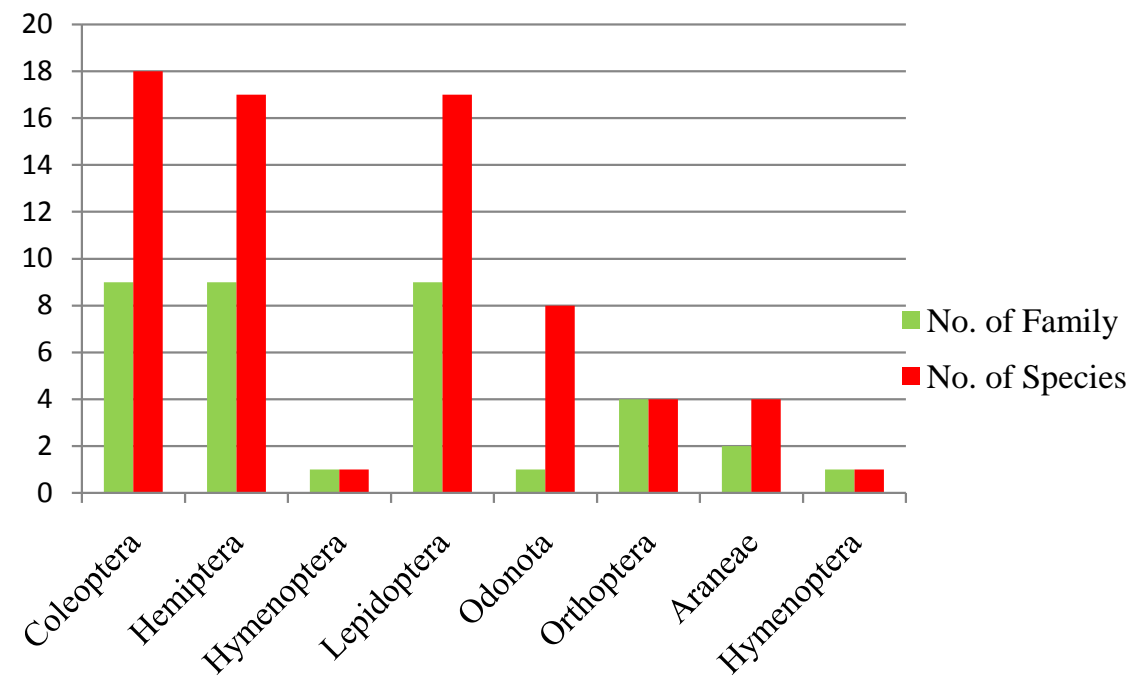

Figure 2. Species composition of family level of arthropod insect species in Taungoo environs.

In the study area of paddy field ecosystem, as relative abundance categories, most species are rare species in both monsoon (55 species) and summer (51 species) the uncommon species category was 12 species in Monsoon rice and 16 species in summer rice fields. No common species was assessed in both seasons. Actually, the spiders are not included in the insect group, here we assessed the abundance categories included with the spider species. However, this paddy field was well and sustainable ecosystem (Table 3 and Figure 3 ).

As a agricultural aspect, In the study area of paddy field ecosystem, three growing seasons of the species number and individual numbers of insects and spiders were observed to varied in monsoon and summer rice growing seasons. During the monsoon season, the same numbers of species (69 species) was observed in 
Table 3. Abundant category of recorded insect species in the study areas.

\begin{tabular}{ccc}
\hline Abundance category & No. of species Monsoon & No. of species in Summer \\
\hline Rare & 55 & 51 \\
Uncommon & 12 & 16 \\
Common & 0 & 0 \\
Frequent & 2 & 2 \\
Abundance & 1 & 70 \\
Total species & 70 & 1 \\
\hline
\end{tabular}

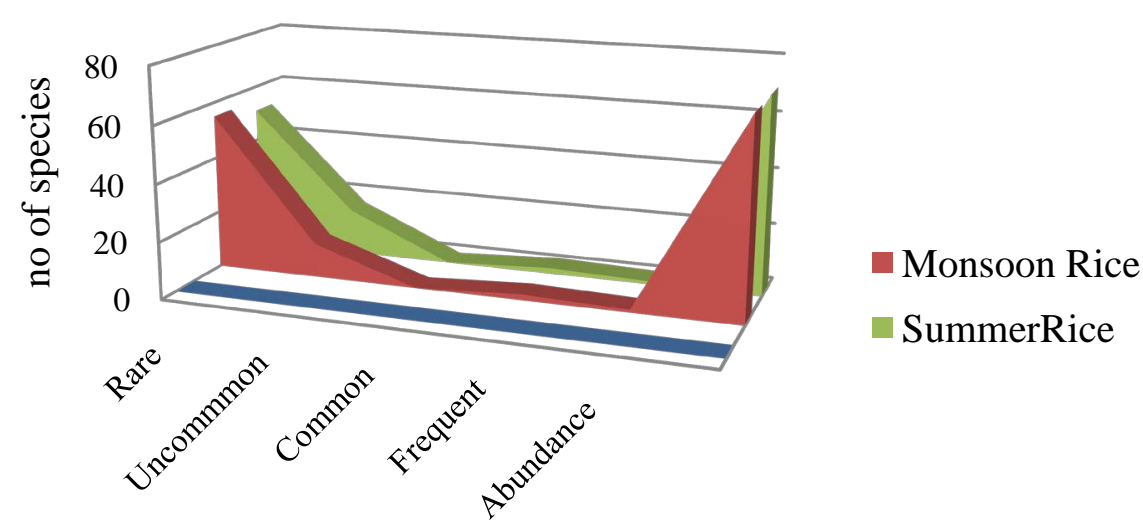

Figure 3. Abundant category of recorded insect species in the study areas.

three growing stages although particular species was found to vary with growing stages (Table 4). Total number and individual numbers of each and all observed species were logically difference in the growing stages. The different types of pest insects, such as stem borers, leaf folders, grain eaters were found with respective growing stages. Consequently, insect predator relationships between pests and carnivorous species were found to commonly specific.

According to the assessment on the Shannan species diversity index, the value was distinctly higher in monsoon season $\left(H^{\prime}=4.52 \mathrm{E}-02\right.$, with $\left.E=6.46 \mathrm{E}-04\right)$ than in summer season $\left(H^{\prime}=2.5482\right.$, with $\left.E=0.0364\right)$ respectively (Table 5). The typical values are generally between 1.5 and 3.5 in most ecological studies, the index is rarely greater than 4 according to the internet assessed. Hence, the paddy fields in the Taungoo environs were highly diverse and still healthy ecosystem.

\section{Conclusion}

Paddy field ecosystem located in Taungoo environs is highly diverse and still healthy ecosystem inhabiting a total of 71 insect species belonging to 40 families under eight orders, including 18 species of beetles, nine species of bugs, eight species of dragonfly, five species of butterflies, four species of leafhoppers, plant hoppers and moths, three borer and spiders, two crickets, one species of skippers, grass hopper, hispa, ant, weevil, hairy caterpillar, leaf roller, katydid, thrips, 
Table 4. Comparison of insect species in different growing stages and seasons.

\begin{tabular}{ccccc}
\hline \multirow{2}{*}{ Growing stage } & Monsoon & Rice field & Summer & Rice field \\
\cline { 2 - 5 } & No. of species & No. of individuals & No. of species & No. of individuals \\
\hline Plantation & 69 & 7349 & 59 & 7166 \\
Flowering & 69 & 17,517 & 63 & 10,116 \\
Ripening & 69 & 11,113 & 61 & 3521 \\
Total numbers & & 35,978 & & 20,803 \\
\hline
\end{tabular}

Table 5. Comparative diversity value of summer and Moon son of Taungoo environ.

\begin{tabular}{|c|c|c|c|c|}
\hline Scientific name & Summer Rice & $P 1 \ln P i$ & Moon Son Rice & $P i \operatorname{Ln} P i$ \\
\hline 1. Xestobiumrufovillosum & 55 & 0 & 400 & $1.310 \mathrm{E}-05$ \\
\hline 2. Heterobostrychusaequalis & 5 & $-3.22 \mathrm{E}-05$ & 136 & $-1.390 \mathrm{E}-05$ \\
\hline 3. Harpalusrufipes & 135 & $-1.04 \mathrm{E}-02$ & 171 & $-1.681 \mathrm{E}-05$ \\
\hline 4. Micraspis discolor & 110 & $-7.39 \mathrm{E}-03$ & 327 & $-7.930 \mathrm{E}-06$ \\
\hline 5. Aulocophorafoveicollis & 99 & $-6.18 \mathrm{E}-03$ & 214 & $-1.836 \mathrm{E}-05$ \\
\hline 6. Aulocophoranigripennis & 92 & $-5.48 \mathrm{E}-03$ & 215 & $-1.839 \mathrm{E}-05$ \\
\hline 7. Cassodaflaveola & 175 & $-1.58 \mathrm{E}-02$ & 252 & $-1.747 \mathrm{E}-05$ \\
\hline 8. Gastrophysaatrocyanea & 289 & $-3.46 \mathrm{E}-02$ & 986 & $7.571 \mathrm{E}-04$ \\
\hline 9. Hoplasaenideacapitata & 0 & $0.00 \mathrm{E}+00$ & 361 & $3.020 \mathrm{E}-07$ \\
\hline 10. Monoleptaaustralis & 0 & $0.00 \mathrm{E}+00$ & 164 & $-1.633 \mathrm{E}-05$ \\
\hline 11. Dicladispa armigera & 103 & $-6.61 \mathrm{E}-03$ & 238 & $-1.807 \mathrm{E}-05$ \\
\hline 12. Caulophilusoryzae & 11 & $-1.33 \mathrm{E}-04$ & 219 & $-1.838 \mathrm{E}-05$ \\
\hline 13. Anthrenus sp. & 0 & $0.00 \mathrm{E}+00$ & 273 & $-1.589 \mathrm{E}-05$ \\
\hline 14. Hydrophilusinquirenda & 426 & $-6.09 \mathrm{E}-02$ & 1153 & $1.196 \mathrm{E}-03$ \\
\hline 15. Heteronychuslioderes & 320 & $-4.03 \mathrm{E}-02$ & 214 & $-1.836 \mathrm{E}-05$ \\
\hline 16. Phyllophaga sp. & 215 & $-2.19 \mathrm{E}-02$ & 190 & $-1.779 \mathrm{E}-05$ \\
\hline 17. Paederus dermatitis & 0 & $0.00 \mathrm{E}+00$ & 487 & $5.552 \mathrm{E}-05$ \\
\hline 18. Xylodromus sp. & 205 & $-2.03 \mathrm{E}-02$ & 183 & $-1.749 \mathrm{E}-05$ \\
\hline 19. Stenocoris sp. & 337 & $-4.35 \mathrm{E}-02$ & 390 & $9.518 \mathrm{E}-06$ \\
\hline 20. Leptocorisaoratorius & 551 & $-8.60 \mathrm{E}-02$ & 219 & $-1.838 \mathrm{E}-05$ \\
\hline 21. Cofona spectra & 187 & $-1.76 \mathrm{E}-02$ & 252 & $-1.747 \mathrm{E}-05$ \\
\hline 22. Empoascafabae & 208 & $-2.08 \mathrm{E}-02$ & 301 & $-1.246 \mathrm{E}-05$ \\
\hline 23. Nephotettixvirescens & 15 & $-2.31 \mathrm{E}-04$ & 315 & $-1.020 \mathrm{E}-05$ \\
\hline 24. Recilia dorsaliszigzag & 15 & $-2.31 \mathrm{E}-04$ & 35 & $-2.205 \mathrm{E}-06$ \\
\hline 25. Corixapunctata & 0 & $0.00 \mathrm{E}+00$ & 325 & $-8.323 \mathrm{E}-06$ \\
\hline 26. Rhynchomitramicrorhina & 395 & $-5.47 \mathrm{E}-02$ & 817 & $4.228 \mathrm{E}-04$ \\
\hline 27. Phytocoirs sp. & 144 & $-1.15 \mathrm{E}-02$ & 259 & $-1.705 \mathrm{E}-05$ \\
\hline 28. Scolopostethuspictus & 2144 & $-3.18 \mathrm{E}-02$ & 1945 & $4.933 \mathrm{E}-03$ \\
\hline 29. Pangaeusbilineatus & 15 & $-2.31 \mathrm{E}-04$ & 340 & $-5.090 \mathrm{E}-06$ \\
\hline 30. Scotinopharacoarctata & 12 & $-1.52 \mathrm{E}-04$ & 280 & $-1.520 \mathrm{E}-05$ \\
\hline 31. Dysdercuscingulatus & 271 & $-3.14 \mathrm{E}-02$ & 307 & $-1.158 \mathrm{E}-05$ \\
\hline 32. Sirtheneadimidiata & 445 & $-6.46 \mathrm{E}-02$ & 196 & $-1.801 \mathrm{E}-05$ \\
\hline
\end{tabular}




\section{Continued}

\begin{tabular}{|c|c|c|c|c|}
\hline 33. Nephotettix nigropictus & 368 & $-4.94 \mathrm{E}-02$ & 532 & $8.549 \mathrm{E}-05$ \\
\hline 34. Nezara viridula & 0 & $0.00 \mathrm{E}+00$ & 155 & $-1.563 \mathrm{E}-05$ \\
\hline 35. Sogatella furcifera & 82 & $-4.51 \mathrm{E}-03$ & 193 & $-1.793 \mathrm{E}-05$ \\
\hline 36. Solenopsisgeminata & 0 & $0.00 \mathrm{E}+00$ & 539 & $9.067 \mathrm{E}-05$ \\
\hline 37. Oxyachinensis & 245 & $-2.69 \mathrm{E}-02$ & 245 & $-1.781 \mathrm{E}-05$ \\
\hline 38. Gryllustexensis & 350 & $-4.60 \mathrm{E}-02$ & 211 & $-1.837 \mathrm{E}-05$ \\
\hline 39. Anaxiphasp & 0 & $0.00 \mathrm{E}+00$ & 1 & $-4.546 \mathrm{E}-09$ \\
\hline 40. Conocephalusfasciatus & 245 & $-2.69 \mathrm{E}-02$ & 280 & $-1.520 \mathrm{E}-05$ \\
\hline 41. Scirphphagapraelata & 255 & $-2.86 \mathrm{E}-02$ & 413 & $1.818 \mathrm{E}-05$ \\
\hline 42. Scirphphaga intertulus & 198 & $-1.93 \mathrm{E}-02$ & 82 & $-7.683 \mathrm{E}-06$ \\
\hline 43. Marasmia exigua & 264 & $-3.01 \mathrm{E}-02$ & 772 & $3.518 \mathrm{E}-04$ \\
\hline 44. Creatonotosgangis & 209 & $-2.10 \mathrm{E}-02$ & 182 & $-1.743 \mathrm{E}-05$ \\
\hline 45. Laeliacoenosa & 149 & $-1.22 \mathrm{E}-02$ & 137 & $-1.399 \mathrm{E}-05$ \\
\hline 46. Orygia sp. & 424 & $-6.05 \mathrm{E}-02$ & 350 & $-2.650 \mathrm{E}-06$ \\
\hline 47. Hydrellia philippina & 243 & $-2.66 \mathrm{E}-02$ & 77 & $-7.063 \mathrm{E}-06$ \\
\hline 48. Pelopidas mathias & 708 & $-1.16 \mathrm{E}-01$ & 323 & $-8.705 \mathrm{E}-06$ \\
\hline 49. Theretrashendurneensis & 590 & $-9.37 \mathrm{E}-02$ & 383 & $7.139 \mathrm{E}-06$ \\
\hline 50. Danaus chrysippus & 589 & $-9.35 \mathrm{E}-02$ & 278 & $-1.540 \mathrm{E}-05$ \\
\hline 51. Junoniaalmana & 730 & $-1.20 \mathrm{E}-01$ & 768 & $3.454 \mathrm{E}-04$ \\
\hline 52. Junoniaatlites & 435 & $-6.26 \mathrm{E}-02$ & 232 & $-1.825 \mathrm{E}-05$ \\
\hline 53. Melanitis leda ismene & 336 & $-4.33 \mathrm{E}-02$ & 144 & $-1.467 \mathrm{E}-05$ \\
\hline 54. Euremahecabe & 458 & $-6.72 \mathrm{E}-02$ & 257 & $-1.714 \mathrm{E}-05$ \\
\hline 55. Chilo polychrysus & 1111 & $-1.73 \mathrm{E}-01$ & 521 & $7.759 \mathrm{E}-05$ \\
\hline 55. Chilo suppressalis & 1015 & $-1.64 \mathrm{E}-01$ & 477 & $4.957 \mathrm{E}-05$ \\
\hline 56. Cnaphalocrocis medinalis & 255 & $-2.86 \mathrm{E}-02$ & 123 & $-1.254 \mathrm{E}-05$ \\
\hline 57. Acisomapanorpoides & 19 & $-3.52 \mathrm{E}-04$ & 102 & $-1.013 \mathrm{E}-05$ \\
\hline 58. Brachythemiscontaminata & 85 & $-4.78 \mathrm{E}-03$ & 69 & $-6.073 \mathrm{E}-06$ \\
\hline 59. Crocothemiserythraea & 120 & $-8.54 \mathrm{E}-03$ & 1985 & $5.199 \mathrm{E}-03$ \\
\hline 60. Diplacodesnebulosa & 372 & $-5.02 \mathrm{E}-02$ & 1011 & $8.157 \mathrm{E}-04$ \\
\hline 61. Diplacodestrivalis & 446 & $-6.49 \mathrm{E}-02$ & 797 & $3.901 \mathrm{E}-04$ \\
\hline 62. Neurothemistulliatullia & 418 & $-5.93 \mathrm{E}-02$ & 937 & $6.491 \mathrm{E}-04$ \\
\hline 63. Orthetrumsabina & 808 & $-1.34 \mathrm{E}-01$ & 819 & $4.265 \mathrm{E}-04$ \\
\hline 64. Trithemiskirbyikirbyi & 287 & $-3.42 \mathrm{E}-02$ & 1112 & $1.078 \mathrm{E}-03$ \\
\hline 65. Argiopecatenulata & 323 & $-4.09 \mathrm{E}-02$ & 1574 & $2.825 \mathrm{E}-03$ \\
\hline 66. Argiopecatenulata & 449 & $-6.54 \mathrm{E}-02$ & 1048 & $9.070 \mathrm{E}-04$ \\
\hline 67. Tegenaria $s p$. & 463 & $-6.83 \mathrm{E}-02$ & 1457 & $2.294 \mathrm{E}-03$ \\
\hline 68. Nesticuscellulanus & 332 & $-4.26 \mathrm{E}-02$ & 935 & $6.450 \mathrm{E}-04$ \\
\hline 69. Nilaparvata luges & 170 & $-1.51 \mathrm{E}-02$ & 776 & $3.58 \mathrm{E}-04$ \\
\hline 70. Stenchaetothrips biformis & 0 & 0 & 3517 & 0.021787407 \\
\hline Total & 21228 & $-2.50 \mathrm{E}+00$ & 35,978 & 0.04520 \\
\hline Shannon Weiner index value & $H^{\prime}=\sum P i \operatorname{Ln} P i$ & 2.5482 & & $4.52 \mathrm{E}-02$ \\
\hline Shannon Evenness index value & $E=H^{\prime} / S$ & $-3.57 \mathrm{E}-02$ & & $6.46 \mathrm{E}-04$ \\
\hline
\end{tabular}


maggot and water boatmen. 41 species of pest species, 18 species of predator species and 12 species of beneficial species were recorded from monsoon rice field. According to abundance category, rare species was highest (55 species) which follows uncommon species (12 species), frequent ( 2 species) and abundance (one species). It could be assumed as balance ecosystem. Among three growing stages, insect was collected the most in flowering stage and the lowest was in the plantation stage. In the comparison of monsoon and summer season, the most species and individual numbers were recorded in monsoon season.

\section{Conflicts of Interest}

The authors declare no conflicts of interest regarding the publication of this paper.

\section{References}

[1] IRRI (1989) IRRI toward 2000 and Beyond. IRRI, Los Banos.

[2] Alam, M.Z. (1965) Insect Pests of Rice in Eastern Pakistan and Their Control [Revised). Agriculture Information Service, Dept. of Agril., B.G. Press, Decca, 96 p.

[3] Alam, S. (1977) Checklist of Rice Insect Pests of Bangladesh. In: Literature Review of Insect Pests and Diseases of Rice in Bangladesh, BRRI, Gazipur, 79-90.

[4] Alam, S., Catling, H.D., Karim, A.N.M.R., Alam, M.S. and Quraishi, N. (1981) Checklist of Rice Insect Pests of Bangladesh. Bangladesh Journal of Zoology, 9, 91-96.

[5] BBS (2009) Statistical Year Book of Bangladesh 2008. Bangladesh Bureau of Statistics, Planning Division, Ministry of Planning, Government of Peoples' Republic of Bangladesh, Dhaka.

[6] BRRI (1993) Annual Report. Bangladesh Rice Research Institute, Gazipur.

[7] BRRI (1997) Annual Report. Bangladesh Rice Research Institute, Gazipur.

[8] BRRI (2000) Annual Report for July 1998-June 1999. Bangladesh Rice Research Institute, Gazipur.

[9] BRRI (2001) Annual Report for July 1999-June 2000. Bangladesh Rice Research Institute, Gazipur.

[10] BRRI (2007) Annual Report for July 2005-June 2006. Bangladesh Rice Research Institute, Gazipur.

[11] BRRI (2009) Proceedings of the BRRI Annual Research Review for 2007-2008, Held on 15-18 March 2009. Gazipur, Dhaka.

[12] Stiling, P. (1999) Ecology Theories and Application. 3rd Edition, Prentice-Hall, Inc., Upper Saddle River.

[13] Kumar, S. and Sivaperuman, C. (2005) Bird Community Structure in Ranthambore National Park. Tiger Paper, 32, 16-17.

[14] Bingham, C.T. (1905) The Fauna of British India, Including Ceylon and Burma, Butterflies Vol. I. Taylor and Francis, London, 511 p.

https://doi.org/10.5962/bhl.title.100748

[15] Bingham, C.T. (1907) The Fauna of British India, Including Ceylon and Burma, Butterflies Vol. II. Taylor and Francis, London, 480 p.

[16] Talbot, G. (1939) The Fauna of British India Including Ceylon and Burma. Butter- 
flies Vol. I. Taylor and Francis, London, 599 p.

[17] Kinyon, S. (2004) A Field Guide to the Butterflies of Myanmar Smithsonian Institution. No. 148, Botahtaung Township, Yangon, 196 p. 